Dr. M. L. Ravitcir, Louisville, Isy.: If I understund correctly, Captain Nichols eriticizes the older writers for their stand that the chancre should be enucleated, preventing thereby the secondary stage with its concomitant eruption. 'To my mind, the theory of the older writers is very plausible. No doubt the elancre is the initial trouble and it was wisely called the initial sore. Going into the detail of etiology of syphilis, we may sum up the process in this way: The patient was exposed to syphilis. The spirochetes were lodged, let us saly, on the lighly sensitized skin of a certain organ. The spirochetes constituting a foreign protein and an irritunt to the skin, Nature tries her best to throw them ofl by means of serums and other fluids. Sometimes the battle is sucecss. ful; the doors are successfully biured ngaiust the entrance of the spirochetes into the general circulation. Sometimes Nature fails to kill the spirochetes in the chance with the aid of protective fluids. Then, the spirochetes go deeper, nle absorbed by the lymplintics and blood-vessels, and a general infection is the result. Nature then makes her second ellort and sends out more protective fluids; we have then the secoulary or eruptive stage. Nature fails; the system becomes sensitized. Nature not being able to help the patient, the latter comes to the medical man. Chemical means are applied. Mercury and arsenic are used, the latter in the new form of salvarsan. But salvalsan is not renlly a new remedy. Arsenie was used by the same old writers who advocated enucleation of the cliancre. No donbt both mercury and salvarsan are good remedies. The first is undoubtedly a specific if nsed rightly. The latter is a good adjunct and call be used in obscure cases, particularly when mereury cannot reach the latent spirochetes. Sometimes neither remedy completely eradicates the disease. Like the gonococi in gonorrhen, the spirochetes in syphilis may also assume a latent form, and when the borly becomes weakened, they may revive and become active again, callsing a new eruption. Some writers may assert that the patient las berome reinfected; but this is not so. The point I. want to make is that the old writers were fully justified in advocating enucleation of the chancre and that salvarsan or arsenic is not a new remedy. Nothing is new in this world.

Dir. Hibeýo Noavcili, New York: I forgot to express my views about the cycle in the life of the spirochete. It is first bred very near home; and it will go around in the spiral form near lome as long as the condition of the environment remuins unfavorable, but not dying out. Then, when the condition of the environment improves, the spiral forms sprout and form these granules, which afterward grow into normal. sized spirochetes. 'That is the time of life and the stage in which one finds the spirochetes in the primary stage of the disease. This stage may last a year or longer. The immunity reaction of the body then becomes so marked as to restrain the growth of the spirochetes. The unfavorable condition persists, and it may force the spirochetes into the sporulation form. Of course, this is all only speculation, hased on the findings in the pure cultures. All the forms of which $I$ have spoken can be demonstrated, however; yet, to be sure, we lave to lave clinical conditions also bearing on this point. The study of latent syphilis is interesting in conncetion with the various forms of spirochetes found.

J). Hosm 7. SwJjt, New York: A case of optic atroplyy which began about ten months after an intramusciular injec. tion of an sily suspension of the drug cansed us to abandon the intramuscular use of salvarsau. The atroplyy wis arrested immediately on removal of the necrotic area at the site of the injection. Investigation of the rate of absorption of arsenic from the site of intramuseular injections in rabbits sliowed that the absorption was so slow that ten weeks after the injection between 5 and 20 per cent. of the arsenic still remained in the muscle. There was extensive necrosis at the site of all the injections. With neosalvarsan there is at necrosis having a similar gross appearunce. Until we know that the rate of absorption from intramuscular injections is quite rapid we should probably continue the intravenous injections of neosalvarsan.

Dr. Jolin A. Founyce, New York: I have had more or less to do with the treatment of syphilis during the past thirty ycars. I can truthfully sny that in the last two years 1 lave sech more patients restored to health by salvarsan alone or combined with mereury than in all of my previous expe. rionce. The drug is unquestionably a specific spirochetal poison and when administered enrly in the disease in doses sufliciently litrge it will abort a certain percentage of cascs of syphilis. If it does not destroy all of the spirochetes it is because they are not reached by it. In such eases an inter. miltent form of treatment with a combination of snlvarsan and mercury is necessary to cradicate the infection. The drug materialiy shortens the period of treatment of the discase and heals the contagions lesions within forty-eight hours to a week. In the City Ilospital with which I am connected such patients were formerly treated for months in many cases with persistence of the rontagions lesions. They would frequently leave the hospital with contrgious-sores and become a menace to those around them. If the ding does nothing more than limit the infectiousness of these individuals it is an excedingly important addition to therapenties. In regard to the danger of intravenous treatment I have given over 1,000 such injections and have never seen any serious symptoms except in one case. Since the improvement in the technie by the use of fresh distilled water the intravenous injection of salvarsan is practically as safe ns an intramuscular injection of mercury.

Another point I wish to protest against. is the indiscriminate curting down on the veins in order to administer the drig. In the great majority of cases this is absolutely unnec. essiry as the veins can usually be rendered visible or can be feit and the needle introduced with little trouble. Jn my experience during the past two years I lave not in a single in.tance found it necessary to resort to this procedure. frequently, after the veins have been eut down on, they are obliterated and it is exceedingly diflicult to administer sub. sequent injections to these patients. Furthermore it marks the patient for life and indientes to the trained observer the nature of the treatment which the patient has received.

\section{THE TEACHING OF SYPIIILIS}

\section{TIIE ATTITUDE OF HOSPITAL BOARDS TO TIIS DISISASE *}

\section{WILLIAM 'IIOMAS CORLETT, M.D., L.R.C.P., (JoNi.)} ${ }^{1}$ rofessor of Derinatology and Syphilology, Western Reserve University

\section{CI.EVELAND}

In the evolution of the American medical college it lats been necessary from time to time to call attention to the object for which the medical school exists. Primarily, in training men to supply the need of a rugged and rapidly increasing population, medical colleges sprang up until their number became excessive, and the quality of instruction furnished failed to keep pace with the demand. At that time, as in the beginning, those who desired to pursue advanced stidy were compelled to seek such training in the medicul cunters of Europe. Will but few exceptions such wes tl:e condition previous to the beginning of the present ireade.

'The first change in the primitive régime was in the revelopment of the laboratory. This involved an expenditure of money that wrought a double benefit, for it not only improved the curriculum but rendered medical schools unprofitable and consequently impossible as a private business enterprise.

With the medical school on a university basis, and with the necessary eudowment, while no one would wish to belittle the importance of the laboratory, for it furnishes the very foundation to medical training, yet, the time has now arrived when careful attention should

- IRead In lhe Sectlon on Dermatology of the Amedican Medical Associatlon, flt the Sixty.'llil'd Annual Session, beld at Atluntic clty, June, 1912. 
likewise be given the clinical chairs. Heretofore, in many schools, this has been impossible on account of insufficient endowment, but in the future, elinical chairs must be placed on a teaching basis, with sufficient endow. ment to secure and encourage the best a competent teacher has to give.

'The present need of medical education in this country is: (a) the training of men to become general practitioners of medicine, in other words, thic making of competent family doctors; (b) the fitting of men for special fields of work.

The student primarily should be taught the essentials of medicine, and if at this stage he elect to talie up a general practice he should also be taught the limitations to which he can safely go fou the best interests of his patients and his own reputation. It is in this primary school of medieine, the output of which is the general practitioner, that much that is now taught slould he eliminated from the primary grade, while other subjects, now neglected or inadeguately taught, should be more thoronghly dwelt on.

'The medical man may not at first be called on for' any of the more difficult surgical procedures ; even should opportunities for such work occul, good jurloment would. Jestrain him, for withont special posternduate training for this work his reputation as well as the life of his patients would suffer the utmost peril. He is, however, liable to encounter the initial lesion of syphilis. Here the merest tyro in medicine feels himsell compotent. Mistakes made, while not so immediately appa!ling, nol so apparent as in the former instance, are of the grivest monent, for on his knowledge depends the welfare, il not the life, of the patient as well as those with whom he may be associated by family or other tics. It is now conceded that during the first few months more can be done toward cardicating the disease than at any other' period. 'The practitioner, theref'ore, should be competent to recognize the aflection-should be fully cognizant of its gravity and the most approved methorls of treatment of this very common and very important alfectionimportant to the patient as well as to the eommunity in which he lives.

During a long course as medical tencher I have repeatedly had occasion to note the lack of exact knowledge of syphilis possessed by candidates for graduation or hospital appointment. The cause may be traced primarily to the curriculum and the alisence of correlation among teachers. Not only should the closest relation be encouraged between the laboratory and the elinic, but a more exnct correlation should exist among the clinical teachers of a medical college. In no subject is this need more apparent than in the teaching of syphilis. Previous to the present decade there might lave been some excuse for the random and inefficient manner in which this affection was taught in the medical schools of this conntry, but since Schaudinn and Foffmann discovered the active agent of syphilis and its ease of demonstration, since Wassermann pointed out some of the possibilities of the serum test in determining the presence or alsence of syphilis in a riven case and since lihrlich led the way to its more rapid extinction, there is need of more thoroughly trained teachers to instruct the student in this disense.

In $\mathbf{1 8 8 9}$ the Western Reserve University established a chair of diseases of the skin and syphilis, and while systematic instuction was given in syjhilis, it was nevertheless hampered by the haphazard distribution of clinj(al inaterial.
In the distribution of cases in most hospitals and clinies syphilis is sent to one depnutment or mother, according as the most noticeable symptom is on the skin, in the brain, the eye or the internal visecra, liven the genito-urinary surgeon in some instances claims it as his own. This was the custom at Lakeside Mospital previous to the present year, with the result that patients were discliarged "cured" after the special organ involved was restored to its normal condition. Again, students were conlused on account of the multiplicity of teachers and obtained no thorough or systematic conception of the discase. Furthermore, the linge perecntage of reentries for "relapse" demonstrated most forcibly the inndcquacy of the system and the harm it was cloing both to the patient and to the student.

Since the beginning of the present year the following rule has been adopted at the out-patient department of Takcsicle Hospital: On entering, of as soon thereafter as the disease is recognized as syphilis, the ease is sont to the department of slin diseases and syphilis. In case particular organs, as the eye, require more specialized troatment the case is referred to the eye department, which in turn returns it after completing such special treatment to the regular departinent for further systematic treatment of discharge. The results thus far lave shown a marked improvement in the tratment and teaching of this disease.

In place of the lack of interest in transitory patients who came only sufficiently long to be temporarily relieved, a high percentage of patients now remain until discharged, and many return when requested, for further observation. 'The difficulty leretofore, as at present, is that many of the departments are manned by men in general practice, who give this time in exchange for such axperience or patients as they inay be able to acquire. Since the appointment of an executive oflicere who is a medical man and who superintends the distribution of clinical material, the out-patient service has been more and more sulisfactory and better results are obtained to both patient and student than was previously found possible.

\section{IIOSPITAL PROVISION FOR SYPHIIIS}

Most hospitals not only make no provision for syphilis but refuse patients who seek admission for this disense. In the City of Cleveland only one hospital receives syphilitics, the City or Municipal Hospotal; at the same time, in all hospitals there is a very high pereentage of syphilities admitted, because the disease is not recognized and because the patients, admitted for other affections, are found to be also syphilitic. This applies to all departments with about equal frequency. Even orderlies and nurses employed by the hospital inve been found to be in the most active stage of the affliction. More tanger is encountered in these rantom, unknown cases than when special wards are provided and proper precautions are olsserved in their management. Moreover, it demonstrates the utter futility of atteupting their complete exclusion. Formerly the need was less urgent for such accommolation thin at present. With the treatment by salvarsan it is inclispensable to have such patients admitted to the hospital for short periods. Prompt neasures at the onset will prevent the danger that always exists to others, and affords the most favorable opportunity of eradicating the disease from the patient's system. In all hospitals, therefore, a male and a female ward should be established for syphilis. In this regard, boards of management and superintendents should be better informed concerning the frequency and 
the gravity of syphilis and the relation which the disease bear's to the general community.

The mistake has arisen in looking on syphilis as a disease confined to the low and vile, while in reality it is encountered in all grades of the moral and social scale; furthermore, the number of blameless persons aflicted with this affection is remarkably high. If: special provision were made, there would be far less jikelihood of such cases being scattered promiscuously through the various services of a hospital as now occurs under the rule of exclusion, which is wholly theoretic, for in actual practice it does not exclude: Nor should these cases be excluded.

\section{CONCLUSIONS}

From the foregoing it seems evident that syphilis should be taught by the creation of a special department; that so far as possible all phases and forms of the aftection should be taught in, or at least be under, the supervision of this department; that laboratory facilitics should be furnislied and manned by a competently trained staff, and that hospital provision is imperative both in better treating the discase and guarding the safety to otliers in the institution. The good such an arrangement would do would redound to the eredit of the hospital and tend to safeguard the community in which the hospital is situated.

If it is inexpedient to establish a special chair or department of syphilis the discase should be grouped with diseases of the skin, because most commonly the Jesions of syphilis are found on the skin and an interpretation of these lesions is best entrusted to the trained eye of the dermatologist. In conelusion, he is best equipped to treat skin lesions who, in addition to being trained in the field of general medicine, becomes skilled in observation with the ability to interpret. With the rapid development of serology and other laboratory depurtments, to be skilled in a given field one must, after the genernl foundation has been securcly established, specialize in order to attain that proficiency which concentration alone can give.

3018 Euclid Avenue

\section{ABSTRACT OF DISCUSSION}

Dr. Anner Post, Boston: The idea that the teacher of syphilis has done his duty when he trents syphilis as a neural disease is passing away. Syplitis is recognized us a constitutional disease which involves the whole body. T'o teach syph. ilis properly the tencher must have aid from his collengues. Dr. Corlett's suggestinus as to the way in which such cooperation should be brouglit about deserve serious attention.

It is a serious question how much a teacler of syphilis should be expected to teach his students. He does not need to make syphilograjhers of them but he slould be able to impress on them the general attributes of the disease, so that.whether they practice on the eye or the ear or the internal orguns they may recognize obvious symptoms nutside of their own branch. We nre most of us obliged to depend on ambulatory service and it ought to be possible by some cooperation to connect the cases in the wards with the anbulants.

Dr. Jonn A. Fonnyce, New York: There should be a depart. ment of syphlibography in our modiest schools which should teach in an intensive manuer the general pathology and symp. tomatology of the disease, so that a student could nbtain from one department a general knowledge of syphilis of the skin, viscera, blood-ressels and the nervous system. I do not interid to convey the idea that one man should cover the entire s.lb. ject of syphilis. The finer points in the diagnosis of syplitis asjale from the skin and mucous membrane lesions sliould be tanglut by the departument of medicine, surgery, neurology and ophthalmologg. "The department of syphilis shoud have under' its control a Wassermann laboratory, as at the present time it is impossible to diagnose and treat many of the manifestations of the disense witiout a proper serologic control. The diagnosis of sypliilis should be made as early as possible and when there is any question of doubt the dark field should be employed to clear up the diagnosis. It is only by an eavly recornition of the infection that the abortive treatment by modern methods can be successfully earried out.

J). Whllina A. Pusiey, Chicago: About two years ago I served as chairman of a subcommittee which was appointed for the purpose of suggesting a practionl working plan for the teaching of dermatology in the medienl schools and the time that should be given to it in the curriculum. I was put in the unpleasant position of objecting to the number of hours that almost every other department declared it required. When it came to the department of dermatology, I expected the same objection from others, and very much to my surprise I found nII opposite nttitude; they ngreed that dermatology and syphilis were entitled to liberal consideration. This experience has led me to belicve that if we work in reasomable concert along the lines l)r. Corlett his suggesterl, we might be able to obtain very practicul results in a few yesrs.

1)r. IIfniry C. J3aum, Syracuse: To every one who teaches this subject, there can be but one opinion in regard to the udvisability of carrying out the anggestions made by Dr. Cor. lett, and in order that sometling ciefinite may be nceomplished, I. would suggest that I)r. White appoint a committee to draft regulations which may be submitted to the institution in which syphilis is taught, and which wonld give to them the weight of the opinion of this Section on this subject, the com. mittee to report at the next annual meeting of this Section.

Dr. GEonas 11. lox, New York: We must approach the study of syphilis from various points of view, and the man who teaches syphilis shonld not only understand the cutaneous lesions of the disense, but also syphilis of the eye, throat, nervous system, etr. Most of those tenching this subject are compelieal to limit instruction to the cutuneous symptoms, and 1 believe that one of the best ways to simplify it for students is to use the same terms in degcribing the skin lesions. As it is now, we employ terms carelessly in referring to the cutancous manifestations of sypinilis. Two weeks ago, at a meeting of the Amerierin Dermatological Associntion in St. Lonis, I read a puper calling attention to this fact, and sug. gested a scheme for simplifying the nomenclature of cutaneous syphilis to take the place of the confusing and often inaceurate classificution that is found in many of our text-books.

DR. Isapone JYik, Now Orlenns: 1 think the idea of rele. gating the.tenching of syphilis in our medical schools to any one mun is not practicable at this time. There are compara. tively few men who possens such a specinl knowledge of the subject as to be able to cover the dermatologic, ophthalmo. logic, rlinologic, neurologic and other phases of the subject. There are compuratively few men who oceupy chairs in dermatology who nre proporly qualified to teach syphilis ns it slonld be taught. Under our present system of tencling syphilis, the students receive a certuili amount of instruction regarding it from the various chairs of medicine, surgery and the specialties, but the informntion is not at all crystallized. At the Tulane University we have tried to coopernte in this respect, so that whon the professor of medicine rearehes a certain point in the teaching of syphilis, he anls in the various sperialiats to give a comrse of lectures on the subject in their special loranches. $A s$ it is, the students obtain their knowledge of the subject from too many diflerent sourees, and what is needed is further cooperntion. Syphilis should be given as much prominence as any otler subject in the teaching curriculum.

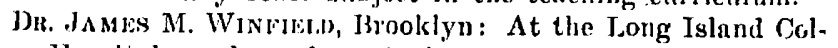
lege llospital we have been trying an experiment somewhat similar to that ontlined by Dr. Jyer. We found that students were receiving a great deal of instruction in regard to syphilis in a rather haphazard way, so the professor on genitourinary discuses ngreed to join with me in an effort to super. vise the teaching of ryphilis. Ife limits himself to the etiology, pathology and the primary lesion, and then I follow with a course of lectures on the cutareous manifestations of the disease. Then the internist, the neurologist, and the varims 
other specinlists take up the subject, limiting themselves to their particular branch, one immediately following the other. Thus far the plan has worked wonderfully well.

Dr. W. T. Contetr, Cieveland: I believe syphilis will be better taught in the future than in the past. and while ind.vidual opinions may diller as to the best way to atlain this end, yet correlation and concentration, whicla will confine ats much as possible the fundamentals to an individual department, will do much to dissominate a bettor and more definte understanding of the affection among medical men.

THE INTENSIVE 'TREA'TMEN'T OF SYPIILIS * HOMER H. SWIFT, M.D.

A. W. M. EJILIS, M.B.
NEW YoRK

The numerous contributions to the study of syphilis in recent years have contimed in many points the previous observations of a purely elinical mature; nlong ofler lines they have settled mooted questions, but they have caused the previous views in regrad to treatment to be largely revised.

The Wassermann reaction has been in use longr enough to establish its place definitely as an indicator of eflicent treatment. While a single negative reaction does not mean that the prtient is cured, a prositive reaction certainly indicates the presence of spirochetes in some palt of the body. In a previous eommunication one of $\mathrm{s}^{1}$ has called attention to the proportion of positive rear. tions in latent syphilis, and its relation to the intensity of treatment as carried out in this country. ln cases of latent syphilis, within three years of the time of infection, 75 per ent. showed a positive ratetion. In late latent cases with two yents trentment or less, 58 per cent. of the jenctions were positive, while 40 per cent. of the patients who had taken from two and one-half to six years' treatment still rave a positive reation. In Paris, Levaditi and Latapie" found 14 per cent. positive reactions in late cases which had roceived intensive mercurial treatment. Isesser:" conchuded that four courses of mereny represent the maximum of efficioncy, because in the late latent stage he obtained 5 t per cenit. negative reactions in patients who had undergone foul courses, while only 53 per cent. of those patients who had taken six courses gave negative reactions. Jesionek and Meirowsky, however, found that although 41 por cent. of patients who hnd tuken four or five courses of treatment gave positive reations, the figures foll steadily to 31 per ecnt. for those who had andergone cight or more courses. With the rule for chronic intermittent treatment laid down by Neiseer, manely, six eourses of mereury in the first three yenrs, the figures still show the presence of positive renctions in over ome-third of all pationts who latal taken three or more years of treatment. In the above-mentioned fignres, the conclusions are drawn from single tests and, considering the temdency of the reaction to relapse when treatment is discontinued, it is probably safe to comclude that 50 per (ent. of all patients with syphilis were insufficiently treared. Antopsy findings on subjects, who had a history of

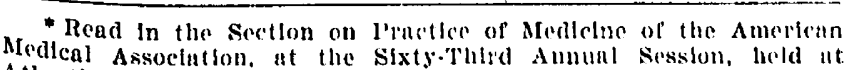
Atluntic City, Jume, 1012.

* From the llosiblal of the leckefeller Instilute for Mealcal Researcl, New York.

1. Swift, H. F.: Areh. Int. Mod, 1810, vl, 020.

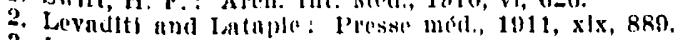

3. Lesser, Is.: Delltsch. ined. Welunsebli, 1910, xxxvl, 116. 4. Jestoneli and Mcirowsky: Milnchen. med. Wohuschr., 1909,
142,207 .

5. Lesser, F.: Deutsch. med. Welunschr., 1909, xxxv, 370 previous syphilis and or section showed some visceral Jesion, contilm this view.

'The advantages of an endy diagnosis of syphilis an hardly be overestimated. From the standpoint of the protection of the community, the enly diagnosis and hence early treatment decrease the danger of the spread of the discase. The secondary period with its mucous fatches and moist condylomas is the most inlections, and the prevention of such lesions will, in a la!ge part, prevent the spread of syphilis.

Of still more importance to the patient is the recorgnition of the life-history of syphilis. It starts as a local inlection and, according to the degree of local reaction and netivity of the virus, remains localized for a longer or shorter period. Alter the spirochetes have broken through the first line of defenses, there is a general invasion of the body. 'The disiemination of the sprochetes doublless takes place largely through the bloodstream doring the last half of the primary stage and in the early secondary period. During this time the blood is most often tomal to be infections. With the blood liom a palient at least three weeks before the ontbreak of the secomdaries, Hoflmamn" was able to induee a typical intial lesion in monkeys. Fruhwald, ${ }^{7}$ in an extensive review of the inlectionsness of the blowl, stales that with one exception spirochetes have never been demonstrated in the blood, either by direet examination or by animal inoculation, later than the tirst six months of the disease.

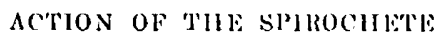

The knowledge of the anly general distribution of the virus gives one an entirely new conception of the progress of the disease. It is probable that all of the lissues are inoculated ealy, and relalpses are simply retapses in sitiu. 'The progression of the eutancons manifestations supports this view. The lesions are at first almost miversal and very superficial, but with each relapse they become more localized, and tend to group nud involve deeper struetures until the gummatons stagis is reached. These very localized relapses probably ille excited by spirochetes long present in the tissues, which the general defenses of the body or therapentic measures have been mable to destroy and which the local reactions "re endeavoring to conquer. It is well established, in both hmman and experimental syphilis, that spirochetes ran lie dormant in lissues for long periods without giving rise to any inflammatory reation. Spirochetes have been found in various tissines of the body which have never shown nny evidence of the discase, and which at; the time of examination showed no tissue reation. 'The llerxhemer renctions, which oreur shortly alter tratment, are often noted in areis where no gross lesion could be demonstrated. Il this renction is comsidered as duo to the liberntion of toxin from spirodetes present at the site of the reaction, it indicates the probubility of such a latent condition of the microorganisms.

'The involvement of the centril nervous system has always been one of the most importunt fentures of syphilis, but only lately are we bogimning to realize how enty this involvement occurs. With the spimal fluid of a patient in the very ealy secombary stane? and withont: nelvous symptoms, Hoflimanns wis able to produce syplibis in a monkey. liavaut" found an increase in cell-count in 67 per cent. of 116 patients with early socomdary syphilis. In parts of the nervous systom

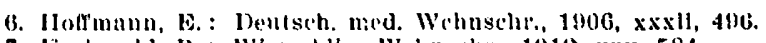

7. linhwald, IR. When. klin. Wehnsedr.. 191: $x \times 5,584$.

8. Hofmunn, la.: Dentsch. med. Wehnsihe, 1912, xxxvili, 313.

v. Lavaut: Ann. de derunt. et de syph., 1003. p. 537. 